\title{
Transgenerational Business Legacies and Intergenerational Succession among the Igbos (Nigeria)
}

\section{Small Enterprise Research}

\author{
Paul Agu Igwe \\ University of Lincoln \\ *Nnamdi O. Madichie \\ Abertay University Dundee \\ n.madichie@abertay.ac.uk \\ Nihar Amoncar \\ University of Derby
}

\begin{abstract}
The main purpose of this study is to highlight the entrepreneurial exploits of an ethnic group within the African context. The research context is the Igbos in Eastern Nigeria who have been celebrated as the pinnacle of African entrepreneurship. The study also draws on the narratives of 25 experienced business owners, and the emerging data thematically analysed to identify key variables associated with transgenerational business legacies and succession. Additional insight on salient cultural and community nuances like the role of Di-okpara (first son), Umunna (sons of the land), Ikwu (members of a Kindred) and Umuada (daughters of the land) were unravelled through interview transcripts and validated by respondents. These insights inform a contribution to the discourse of ethnic or indigenous entrepreneurship, which has both theoretical and policy implications.
\end{abstract}

Key Words: Indigenous Entrepreneurship; Transgenerational Legacy; Intergenerational Succession; Igbos; Eastern Nigeria.

\section{Introduction}

Challenges faced by entrepreneurs in developing countries are overcome through different types of collaborative initiatives such as cultural collaboration and community innovations (Ratten, 2014). Ethnic and Indigenous entrepreneurship is one mechanism to help address many of the economic and social challenges faced by minority groups (Barrett, 2013; Greidanus \& Sharpe, 2017). Also, a growing body of research suggests that entrepreneurial activities are culturally grounded (Bruton, Zahra \& Cai, 2018) and the landscape of family businesses is fundamental to small business growth (Yu et al., 2012; Yuan \& Wu, 2017). 
Families play an important role in entrepreneurship (Arregle et al., 2015; Powell \& Eddleston, 2016) either by offering access to resources or by interfering with work (Zhu, Burmeister-Lamp $\& \mathrm{Hsu}, 2017)$. Other scholars provide insight into how familiness is a strategic resource in a family business, thereby tapping into a key antecedent to sustained performance of family firms (Harms et al., 2012; Kansikas et al., 2012). More so, the interaction between family firms and business resources highlight the importance of social capital (Kwon, Heflin \& Ruef, 2013; Kim, Aldrich \& Keister, 2006) and social relationship with-in and out-with the business organisation (Zellweger et al., 2018).

Assessing the 'Igbos transgenerational business legacy' puzzle through 'familiness' approach is appropriate. Recent studies have established a strong link between entrepreneurial legacy, defined as "the family's rhetorical reconstruction of past entrepreneurial achievements or resilience" (Jaskiewicz, Combs \& Rau, 2015, p. 29). The acknowledgement of family firms' interaction with their localised environment is part of a broader move in the entrepreneurship literature to understand how situational context informs both the nature and the characteristics of entrepreneurial activities and behaviours. The Igbos (located in the Southeastern region of Nigeria) have been described as "naturally enterprising and ingenious" and can be found throughout Nigeria and West Africa (Igwe et al., 2018; Meagher, 2010). The Igbos are culturally homogeneous society and that business tends to be organised along with a strong family pattern (Oyelaran-Oyeyinka, 2004). Against this backdrop, this article examines elements of familiness and transgenerational business legacies of Igbos (a relative disadvantage ethnic minority group) in Nigeria.

Collaborative entrepreneurship in developing economies involves examining the role of collective action that fosters greater society benefits than pure individual gain (Ratten, 2014). Some studies suggest that collaborative entrepreneurship involves the creation and utilization of opportunities made possible by linkages with individuals, businesses and government entities (Naude, Szirmai \& Guedhuys, 2011; Ratten, 2014). The literature on Igbo business history emphasises the importance of family (Igwe et al., 2018; Meagher, 2010). Hence, Igbo's tightly controlled family connections ensure that members of the extended family oversee essential networks of production and distribution (Meagher, 2010). Linked to the social learning theory, Igbo families provide an entrepreneurial leadership platform, which influences youths through role models, providing mastery experiences and socialisation (Igwe et al., 2018). In addition, the extended family and an informal apprenticeship system (Nwaboi system) provide a safe environment for risk-taking, creativity and innovation (Igwe et al., 2018). Therefore, linked to culture, the family become an important element of entrepreneurial 
decisions and behaviour. Consequently, this study seeks to address the following research questions:

Research Question 1: What are the elements of family, cultural and community in the Igbos business life?

Research Question 2: How do Igbo Indigenous entrepreneurship develop and enable entrepreneurial learning, entrepreneurial culture and family business succession?

Research Question 3: What are the implications of all of these revelations about ethnic and indigenous entrepreneurship?

Based on the aforementioned research question, this study seeks to explore, and highlight key components of ethnic entrepreneurship, which include explorations of cultural families (Collins \& Fakoussa, 2015; Authors et al., 2018), the role of family and entrepreneurial behaviours of the Igbos (Madichie et al., 2008). Studies in entrepreneurship collaboration in developing countries examines innovative characteristics and partnerships that encourage community participation (Ratten, 2014). To illustrate these contexts, we draw on qualitative data and interviews with 25 Igbo experienced entrepreneurs and business owners providing unique insights into the ethnic minority business culture, intergenerational succession legacies, thereby casting light on an aspect of African entrepreneurship, which is currently underresearched, but gathering research momentum. The findings were triangulated with newsletters and online information about the Igbos. Following this opening section, the research goes on to interrogate the literature on ethnic minority family businesses drawing upon the notion of 'familiness and transgenerational business legacy, and their intersections with family business succession. This followed by a statement of the research design, data analysis, findings, discussions, conclusions and implications in subsequent sections.

\section{Literature Review}

\section{African Entrepreneurship}

Studies on African entrepreneurship involves understanding the evolutionary dynamics of African entrepreneurial ecosystems such as the role of institutions and sociocultural elements in determining entrepreneurial motivations and behaviours. Scholars portray research in African entrepreneurship as a forward-looking activity (Nwankwo, Madichie \& Ekwulugo, 
2011; Dana, Ratten and Honyenuga, 2018; Igwe \& Icha-Ituma, 2020). However, there is a paucity of research about entrepreneurship in Africa (George et al., 2016; Naudè and Havenga, 2005). In their edited book on African Entrepreneurship: Challenges and Opportunities for Doing Business, Dana et al. (2018) provided some insight into the state of entrepreneurship in Africa, the role of the state in business and entrepreneurship development. One of the key highlights of the book is that institutions are important in Africa for giving stability to entrepreneurship and as a foundation for business development (Ratten \& Jones, 2018). In addition, there is an examination of the role entpreneurship plays in the African economy and SME productivity challenges. The factors identified as affecting investment and productivity include education of the labour force, access to infrastructure, access to finance and corruption (Igwe, Onjewu \& Nwibo, 2018). Exploring how government employees can become entrepreneurs in their later careers, Madichie and Ayasi (2018) provides a historical perspective of the military in governance and the role that entrepreneurship among the retired military officers can play in Nigeria's development. the importance of knowledge and learning in fostering entrepreneurial business practices. Mbeteh and Pellegrini (2018) focuses on entrepreneurship education in developing countries with Sierra Leone. They analyse how entrepreneurship education could become a tool to overcome the rising youth unemployment. These studies highlight some barriers to business development in Africa such as a lack of finance, lack of culture of business succession, increasing insecurity and institutional failure (Igwe \& Icha-Ituma, 2020).

\section{Ethnic Entrepreneurship}

Among the problematic tenets of defining ethnic business, Zhou (2004), described it as businesses whose ownership and membership are tied to a common cultural heritage. The idea highlights that ethnic family businesses possess an inherent competitive advantage due to their unique resources and capabilities generated through family networks (Tata \& Prasad, 2015). Ethnic minority family firms are known to leverage trust to handle sensitive resources (Deakins et al., 2015; Ram et al., 2012) and the dynamics at play within such communities create a unique social wealth that is available to tap (Adendorff \& Halkias, 2014). Anggadwita, Ramadani \& Ratten (2017) examined the relationship between ethnicity and entrepreneurial orientation while positing that the unique elements of the social and cultural contexts of ethnic communities influence their entrepreneurial behaviour.

Ethnic business communities have recently been explored from a social capital perspective by several scholars (Kwon, Heflin \& Ruef, 2013; Light \& Dana, 2013), which help 
us understand the niche contexts of ethnic family businesses and how they use their social context for competitive advantage. Furthermore, networking interactions, trust and kind of information are important in the development and growth of small business owners (Sharafizad \& Coetzer, 2016). Entrepreneurship development within such communities is argued to be created via social capital and is facilitated via networks (Seaman, 2015). It is argued that family businesses can inherit, access, source and build upon and use social capital to gain a competitive advantage (Sundaramurthy, 2008). Scholars have posited that the opportunities and strategies of entrepreneurs are closely linked to their embeddedness in the socio-economic and political environments and that these external factors have a great influence on the behaviour and development of ethnic entrepreneurs (Alvarez et al., 2011; Rath, 2000).

Ethnic family businesses are known to have inherent trust due to their common family ties (Iyer, 2004). Familiness research has become popular in the past few years (Arregle et al., 2015; Barbera, Stamm \& DeWitt, 2018; Kansikas et al., 2012; Powell \& Eddleston, 2016). Habbershon and Williams (1999) postulated the theory of 'Familiness' defined as “... the idiosyncratic firm-level bundle of resources and capabilities resulting from the interactions of the system" (Habbershon, Williams \& MacMillan, 2003, p. 451). Concentrating first on those tenets, 'distinctive familiness' is created by the long-term perspective, shared goals and speedy decision-making (Barret, 2014). Chrisman, Chua \& Litz (2003) later described the concept as “...resources and capabilities related to family involvement and interactions" (p. 468). Limited research has been undertaken to understand how families manage transgenerational entrepreneurship and scholars have identified this to be a major gap in this research domain (Nordqvist et al., 2013).

Entrepreneurial legacies are defined as the rhetorical re-enactment of the entrepreneurial achievements or resilience of the past (Jaskiewicz et al., 2015) while transgenerational entrepreneurship is understood to be the processes through which a family uses and develops entrepreneurial mindsets alongside the resources and capabilities that are influenced by the family to develop new avenues of entrepreneurial, financial and social value across generations (Habbershon et al., 2010). The focus of this research is on 'ordinary succession' (Le Breton-Miller et al., 2004). Le Breton-Miller et al., (2004) posits that it is a concept which focusses on processes and family attributes that characterise the successful transfer of ownership and control but fails to explain how the successors gain the motivation and ability to act entrepreneurially. Considering the importance of family businesses in the economic paradigm of the society, it is essential to further develop research in this area, particularly in non-western contexts to enable new insights to emerge. 


\section{Methodology}

Taking a cue from Nwankwo, Madichie \& Ekwulugo (2011) our methodological approach is qualitative in nature. Indeed, these authors argued that "doing research that is useful to the practice of ethnic entrepreneurship [...] implicitly requires pragmatism and sensitivity to the contextual nature of the phenomenon" (p. 62). It is in the exploration of these multiple realities of our respondents that prompted the need adopt this methodological stance. By so doing we took some systematic steps. First, we set about carefully selecting our sample, by adopting the purposive sampling technique in our sample of Igbo business owners and entrepreneurs. This is deemed appropriate considering that it allows the researcher to focus on the subjects' individual experiences, and so explain the subject's reality (Rolfe, 2006; Palinkas et al., 2015). All business owners investigated had between 10 to 20 years of experience of starting and operating a small to medium enterprises. Sampling is also dependent on the characteristics of the setting, e.g., access, time, vulnerability of participants, and different types of stakeholders (Moser \& Korstjens, 2018).

Second, we resorted to the use of semi-structured interviews as the most appropriate format for uncovering key aspects of business knowledge, economic knowledge, cultural awareness, family, social issues and business legacies of the researched group. This, in our view, enables us decipher, and accommodate, their respective realities. Research participants were briefed on the aim and objectives of the study and informed consent was solicited and granted by every participant involved in the study. All interviews were undertaken in both the Igbo and English language, recorded, transcribed verbatim, and coded to conduct a thematic analysis. The interviews lasted between $50-60$ minutes. In line with previous studies such as Selling \& Svallfors (2019, p. 989), the thematic analysis followed an abductive format, where sets of categories derived from the main research questions were subsequently revised in a stepwise fashion through verification of salient interview quotes and respondent verification. The original categories were consequently amended, collapsed, and/or split, and new categories introduced to cover pertinent interview themes (Selling \& Svallfors, 2019). Thus, categories are obtained which subsume two or more concepts (Jaskiewicz et al., 2015) that enabled thematic presentations of dominant quotes and discussion identified from individual respondents. Local newsletters and online information (see Table 1) were used as a means of validation and triangulation thus enabled further clarifications (Monahan \& Fisher, 2010). 
Table 1: Online News and Information about Igbos

\begin{abstract}
Chinua Achebe - Things Fall Apart
This novel depicts the life of a "primitive Igbo culture" from the life of Okonkwo (the main character). Family is extremely important to the Igbos. Igbo families generally live in compounds and compounds contains one group or a family unit. The head of the compound in a village is generally the oldest male of the compound. The head of the compound is responsible for its family members. Extended families are created upon marriage. Extended family members are always welcome to unannounced visits to the nuclear family. Politically, elders rule Igbo villages not families and married life is the normal conditions for grown-up adults and a condition for membership of elder's forum/council headed by a traditional ruler/king (Igwe, Eze or Chief). Traditional Igbos allowed polygamy and many children from a nuclear family, which was an important indicator of status.
\end{abstract}

The Editors of Encyclopaedia, Igbo People (n.d.)

Trading, local crafts, and wage labour are important in the Igbo economy, and a high literacy rate has helped many Igbo to become civil servants and business entrepreneurs in the decades after Nigeria gained independence. It is notable that Igbo women engage in trade and are influential in local politics.

Wikipedia 2 November (2019)

The Igbo have a unique form of apprenticeship (Igbo: Igba Boy) in which either a male family member or a community member will spend time (usually in their teens to their adulthood) with another family when they work for them. After the time spent with the family, the head of the host household, who is usually the older man who brought the apprentice into his household, will establish (Igbo: iduno) the apprentice by either setting up a business for him or giving money or tools by which to make a living.

Guardian 03 November 2019

The Igbos are one of the largest ethnicities in West Africa. In many parts of Igbo land, it is a common belief that men are superior to their female counterparts, and this view is enforced in many aspects. Making of laws, inheriting property are responsibilities seen to be exclusive to men, while women are groomed to be better daughters, sisters and wives' right from infancy.

Guardian Newspaper 14 March 2019

A perennial issue among the Igbos is the battle between the mind and the purse; between certificate and cash. All over Nigeria, the Igbo are recognised for their entrepreneurial spirit and business acumen. From precolonial times to today, a majority of the country's successful traders and transporters have been Igbo. Many of them began as apprentices and worked their way up, never bothering with the school. The Igbo are also known for ostentatiousness and flamboyance - those with great wealth usually find it difficult to be silent about it.

BBC News 27 April 2016

Igbos have a reputation for exploring faraway lands in search of a better life. Some complain that Igbos are too quick to assimilate and adopt the culture of the host country, others argue this traveller spirit is something to be proud of.

CNN 4 February 2013

From generation to generation, some Igbo have passed down various versions of a migration story framed around Jacob, a patriarch of Judaism. A popular version of the narrative holds that Gad, the seventh son of Jacob, had three sons who settled in present-day south-eastern Nigeria, which is predominantly inhabited by the Igbo. Those sons, Eri, Arodi and Areli (as mentioned in the book of Genesis), are said to have fathered clans, established kingdoms and founded towns still in existence in south-eastern Nigeria today, including Owerri, Umuleri, Arochukwu and Aguleri.

Guardian 16 November 2016

Now, like then, Igbos say they have been marginalised by being excluded from key government posts and denied vital funding for infrastructure development, schools and hospitals.

BBC News 27 April 2016

All these issues are interlinked, fear of marginalisation, identity crises and an endangered language. 


\section{Findings}

Thematically, we separated our finding into four themes that ranged from culture and community factors, family roles, and the roles of first son and male children and the extended families. These variables or salient insights were used to explain the process of transgenerational family businesses transfer and intergenerational succession management.

\section{Cultural, Community and Family factors}

Entrepreneurship is influenced by a nation's economic and social environment (Ratten, 2014). The key themes that emerged interview data (Table 2) reveals important elements to Igbo entrepreneurial spirit, mindset and enterprising orientations. These elements include the role of individualist culture that drives competitiveness and rivalry among the Igbos. There is also the leadership and recognition culture based on wealth status. There is a unique role played by the family unit. Lack of financial access is an obstacle for many entrepreneurs in developing countries and entrepreneurs are always seeking for financial opportunities (Ratten, 2014). The families provide the learning foundation and support (both learning at home, learning in the family business and learning through informal apprenticeship system) that encourages and breed new generations of entrepreneurs, thus driving the Igbos transgenerational business legacies. These have been presented as quotes in Table 2 .

\section{Table 2. Cultural and Family Elements in the Igbos business life}

\begin{tabular}{|c|c|}
\hline Themes & Exemplary phrases from quotes \\
\hline \multirow[t]{5}{*}{$\begin{array}{l}\text { Culture \& } \\
\text { Community } \\
\text { factors }\end{array}$} & $\begin{array}{l}\text { Igbo culture recognises the importance of business and encourages individual } \\
\text { wealth. Those who make it are accorded society recognition such as chieftaincy } \\
\text { titles and maintains prestige and respect in the society. These are the cultural } \\
\text { underlying that drives us the Igbos into the business [005]. }\end{array}$ \\
\hline & $\begin{array}{l}\text { We say in Igbo - 'Igbo enwe Eze' (that is Igbos has no king) but if you want to be } \\
\text { a king in your community and the society, you have to be rich by having a top } \\
\text { government job, being highly educated or going into politics. Business is the more } \\
\text { popular options that Igbos choose and that is why we are doing great all over the } \\
\text { country [007]. }\end{array}$ \\
\hline & $\begin{array}{l}\text { Igbo culture and society respect money and wealth. We encourage our sons and } \\
\text { daughter to seek wealth and bring it back home to our community and help to } \\
\text { develop our community [008]. }\end{array}$ \\
\hline & $\begin{array}{l}\text { The society provides a positive platform, which Igbo entrepreneurship thrive. There } \\
\text { is healthy but sometimes fierce competitions among brothers, sisters, peers, family } \\
\text { verse family and so on when it comes to business engagement [001]. }\end{array}$ \\
\hline & $\begin{array}{l}\text { There is no sentiment of Igbo ethnic brotherly or sisterly relationship when it } \\
\text { comes to business. The culture is very much individualist and status-oriented [017]. }\end{array}$ \\
\hline
\end{tabular}


The younger generations are motivated to join the business by seeing what the older generations have been able to achieve through business venturing. They are encouraged to travel to take risks and business adventures [004].

You are considered a failure if you don't make it and that is what spurs the Igbos to success [025].

Family Roles From young, we are prepared to follow the footsteps of other family members who have made it in business. We are encouraged to pursue business to change the fortune and conditions of our family [003].

Every family wants to be rich and recognised, hence they push their sons to break barriers and achieve entrepreneurial success [015].

Our families nurture the young ones. From the age of 5 years, your mother or father takes you to her stand in the market or shop. When you come back from primary school, you join those in the shops to help out and through that you are groomed for business and you learn the tricks of business [006].

The families are responsible for inculcating the spirit of business creativity and risk-taking. They will let you go to serve as Nwaboi (informal volunteering) even at the age of 12 years [021].

It is the responsibility of every family to prove entrepreneurial training to their children and to support them financially and a back-up plan in the case of failures or adversity [009].

Families take business as a challenge and as a means to compete with other families [011].

You are trained and prepared to be hardworking from childhood. They take you to the farms, to the market, to the shops [013].

Even from the age of 10 years, you are expected to join to serve customers and learn what your family business is all about [001].

The family is the backbone and foundation for Igbo's transgenerational business legacies, they will support you many times as long as is required for you to succeed [019].

\section{Transgenerational Legacies and Intergenerational succession}

Furthermore, we set out to generate information concerning Igbos transgenerational legacies and succession planning and business conflict management. Entrepreneurship development require collaborative power of innovative business practices (Ratten, 2014; Dana \& Ratten, 2017). We found a culture that places high emphasise on male child and particularly fist son and how sons are preferred and prepared to succeed the businesses. In addition, there is a culture of familiness, trust and cohesion among extended families. According to Igwe et al., (2018), Igbo families provide an entrepreneurial leadership platform, which influences youths through role models, providing mastery experiences and socialisation and extended family provides a safe environment for risk taking, creativity and innovation. The Igbo social and business life depends so much on the foundation and support provided by the extended families (Ikwu, meaning Kindred of a village or town). An informal apprenticeship system provides 
entrepreneurial learning that prepares the younger generation to take to business as a way of life (Igwe et al., 2018). As presented in Table 3, elders within the kindred system are powerful. The Elders provides the political, leadership and control of extended family members. It is at the 'Ikwu' or 'Umunna' (sons of the land of a particular village or town) meetings that conflicts, succession challenges and business quarrels are managed and settled.

\section{Table 3. Legacies and Succession Management}

\begin{tabular}{ll}
\hline Themes & Exemplary phrases from quotes \\
\hline The role of Di-okpara & Male child and particularly the first son is important when planning who to \\
(first son) and male & $\begin{array}{l}\text { succeed you in the business. If the first son shows no interest that is where } \\
\text { children }\end{array}$ \\
& $\begin{array}{l}\text { it's down to you as the head to find which of your children that will carry } \\
\text { on the legacy. "You don't want your name to get lost (afamu-efuna)" we } \\
\text { say in Igbo [020]. }\end{array}$
\end{tabular}

We give all the boys the chance to learn the business except those who choose to pursue an educational career. From giving everyone the chance, you monitor, encourage the one or ones that will carry on the business after you have retired or 'gone' (die) [002].

It is tricky if you don't have a male child and when this is the case, the man opts to marry a new wife until he finds male children to take over the legacies of the family [012].

Yes, male children were the focus in the past generations but this generation is different, girls and daughters now play similar roles. Although, this case is still not so popular, especially in the villages [023].

The character of Di-okpara (first son) is very important. The legacy will be doomed if the first son is non-hardworking, intelligence and leader. He might ruin the chances of the other hardworking sons and there will be no legacies [013].

The role of extended families (Umunna, meaning sons of the land)
A key feature of the Igbo transgenerational legacy is the role of the extended families. They will help you to find where to learn the trade and provide you with the support, financial capital, customers and suppliers network (social capital) to start and run the business [014].

The Igbo unity is only achieved through within the Umunna. Every Umunna will support their sons or daughters, you are like one family. You can trust and share business secrets and work as a team. The Umunna provide members with the foundation and social capital to thrive [017].

Extended families provide the platform for Igbo business success [016].

Wherever one goes, he will take his brothers or sister to join or form a business network [024].

Trust is more enforced within the extended family than among the Igbos as an ethnic group. You may not trust a fellow Igbo but you can trust and rely on a member of you 'Umunna' [010].

Conflicts, succession challenges and business quarrels are managed and settled within the Umunna. Elders mediate to settle issues arising from individuals or families and provide sanctions when required [005]. 
The decisions of the elders of the Umunna are final and binding on members [011].

\section{Discussion}

Thematically, this study sought to explore Igbo ethnic entrepreneurship from three main lenses: cultural and family factors influencing Igbos business experience; the process of transgenerational family businesses transfer: and how intergenerational succession and conflicts are managed. Igbo culture recognises the importance of business and encourages individualist characteristics and the society respect money and wealth. The culture provides a positive platform which Igbo entrepreneurship thrive. It encourages fierce intra and interfamily competitions when it comes to business culture. Familiness has been described a strategic resource in a family business (Harms et al., 2012; Kansikas et al., 2012) which highlight the importance of social capital (Kwon, Heflin \& Ruef, 2013; Kim, Aldrich \& Keister, 2006; Zellweger et al., 2018). Igbo families are responsible for inculcating on their children the entrepreneurship spirit, creativity and risk-taking. They provide opportunities for business training, financial capital and social capital such as customers and suppliers network to start and run the business.

According to Ratten (2014), a key perception of collaborative entrepreneurship in developing countries is the use of natural resources that can be adapted from traditional usages to create additional business opportunities and achieve mutual benefits. Drakopoulou, Anderson \& Jack (2004), explained the process of social networks throughout entrepreneurial stages, and maintained that acquiring motivation greatly depends on family influence, especially parental entrepreneurship. They suggested that even specific ethnic and religious traditions of enterprise can be very important network-driven motivators and opportunity perception involves growing entrepreneurs' ideas for new products emerge through market discussions with strong tie contacts, often customers.

Such collaborative entrepreneurship is useful, as it enables needs and resources to be shared so they can become better in the marketplace (Ratten, 2014). Igwe et al., (2018) reveal the indigenous knowledge of Igbo families and entrepreneurial behaviour that highlights the importance of the extended family and the informal apprenticeship/volunteering system in Igbo business culture. Our findings developed four themes that serve as social capital and network points, 'Nwaboi' (informal volunteering); the role of first son (di-okpara), which is closely linked to "afamu-efuna"; the independence and individualist behaviour of the Igbos ("Igbo enwe Eze' - i.e. Igbos has no king); and the entrepreneurship collaborative and cultural initiative - the role of kindred (Umunna). Igbo transgenerational business legacies and succession is maintained by identifying and nurturing sons who can take over the business to ensure its longevity. The behaviour and business character of first son is very important (see Madichie et al. 2008; Madichie \& Nkamnebe, 2010a). If the first son shows no interest, any other male in the family with potential is trained and prepared to take over the business. In addition, where family business conflict arises, the elders of the 'kindred' step in to settle any dispute arising from family business. The decisions of the elders are final and binding on all family members.

There is also the 'Umuada' (Umu means people) of first daughters (Ada) - an association of indigenous women who are influential and powerful, although the group goes beyond the first daughters whose ancestry are traced to a village or town (Guardian 2019; Madichie \& Nkamnebe, 2010b). The Umuada represents the interest of women and serves as a bridge between the women and the men. In some cases, the Umuada also serve as checks on the abuse of power by the council of elders (Guardian, 2019). Taking these in turn, the notion 
of "Nwaboi" (informal volunteering) is symptomatic of the apprenticeship scheme, which commences from about the young age of 12 years amongst the Igbos. Second, the notion of "Di-okpara" highlights the importance and/ or significant role of the male child (normally the first son) to the legacy of the family and any succession plans. It is also linked to the notion "afamu-efuna," which guarantees the lineage among the Igbos. Third, and finally, the moderating role of the 'Umunna' or kindred as arbiters of family and/ or societal disputes. Indeed, the decisions of the elders within the Umunna are final and binding on members of the clan. Through shaping new norms and beliefs and establishment of more effective business processes with better financial frameworks (Ratten, 2014), this enables the development of new markets and cultural innovation that enables Igbos to maintain transgenerational business legacies and intergenerational succession.

\section{Conclusion}

Overall, this study extends the discussions from the 2017 Special Issue on "Indigenous Entrepreneurship" published in this journal by highlighting the need for further research attention on the topic of ethnic entrepreneurship. Entrepreneurship is culturally bound due to individual attitudes towards entrepreneurship differing depending on the level of economic development (Ratten, 2014; Dana \& Ratten, 2017). Indeed, the role of family affinity and/ or networks in leveraging opportunities and making significant contributions to the economic growth of nations is something that has been observed across geographies. Consequently, this study not only contributes to the discourse, but also takes the narrative further as research on the topic continues to amass. In the light of the foregoing, the following implications are highlighted and future research directions suggested.

\section{Managerial and Policy implications}

The context of ethnic and indigenous entrepreneurship presents research, policy and practical implications especially given the dearth of research on indigenous and tribal business and policymakers looking for ways to encourage entrepreneurship in African countries as a means of reducing unemployment and poverty. While the findings from Igbo ethnic entrepreneurship studies cannot necessarily be generalized for all other ethnicity, each elements of the Igbo entrepreneurial spirit and culture raises different issues that support and develop theory and knowledge on the relationship between micro-entrepreneurial success and sustainability, and indigenous entrepreneurship (Cahn, 2008, p. 16).

These findings provide realistic and current examples of how African entrepreneurship is embedded in unique cultural phenomena. Finally, given that African indigenous entrepreneurship is only beginning to gather research interest (George et al., 2016), it is anticipated that the cultural dynamics among ethnic groups and their business exploits be consolidated rather than continue to remain fragmented as is currently the case. Taking a cue from the title of the book by Chinua Achebe, one of the greatest poets of "Igbo" ancestry, scholars cannot let "Things Fall Apart" in this quest to understand and act upon the dynamics and potential of ethnic groups and their contribution to the global economy.

Indigenous entrepreneurs in small private businesses also aim primarily to provide for their family (Collins et al., 2017), hence these has implications on employment and poverty reduction. In addition, studies on Igbo entrepreneurs suggests that Indigenous businesses face both ethnic, tribal and gender discrimination from mainstream society and government. This have implications on migration, informal entrepreneurship, crime, conflicts and wars.

\section{Limitations and future research directions}

Like many studies of this nature, the qualitative approach adopted may be prone to hindsight bias, which is something that Gartner (2007, p. 619) referred to as "the narrative approach 
recognises that a story is never the whole story since any story is embedded in a context". Indeed, there are limitations such as scope and data saturation that can be problematic in qualitative research (Ritchie and Lewis, 2013; Igwe et al., 2019). However, the study has followed a robust qualitative method and validation process and gone ahead to contribute to the amassing research on Indigenous and Ethnic Entrepreneurship in the context of Africa albeit from the purview of Igbo entrepreneurial behaviours and business culture (see, Igwe et al., 2018). In so doing, this study provides a foundation for future replication studies using the similar research procedures in other contexts with indigenous populations (Canada, New Zealand, Africa and Norway) to provide a more holistic understanding of the themes highlighted therein.

\section{References}

Achebe, C. (2006). Things Fall Apart. Originally published: 1958. Publisher: Penguin Classics; 01 edition (26 Jan. 2006) Language: English ISBN-10: 9780141023380

Adendorff, C. \& Halkias, D. (2014). Governance in Immigrant Family Businesses: Enterprise, Ethnicity and Family Dynamics, Ashgate Publishing Ltd, Surrey.

Álvarez, J., Bilancini, E., D’Alessandro, S. \& Porcile, G. (2011). Agricultural institutions, industrialization and growth: The case of New Zealand and Uruguay in 1870-1940. Explorations in Economic History 48(2011), pp. 151-168

Anggadwita, G., Ramadani, V. and Ratten, V. (2017). Sociocultural environments and emerging economy entrepreneurship Women entrepreneurs in Indonesia. Journal of Entrepreneurship in Emerging Economies, 9 (1), 85 - 96.

Arregle, J. L., Batjargal, B., Hitt, M.A., Webb, J.W., Miller, T. \& Tsui, A.S. (2015). Family ties in entrepreneurs' social networks and new venture growth. Entrepreneurship Theory and Practice, 39(2), 313-344.

Barbera, F., Stamm, I. \& DeWitt, R-L. (2018). The Development of an Entrepreneurial Legacy: Exploring the Role of Anticipated Futures in Transgenerational Entrepreneurship. Family Business Review, Vol. 31(3) 352-378

Barrett. M. A. (2013). Editorial. Small Enterprise Research, 20:2, pages 70-75.

Barret, M. A. (2014). Theories to define and understand family firms, In H. Hasan (Eds.), pp. $169-168$

BBC News (2016). Why I stopped mispronouncing my Igbo name. By Nkem Ifejika. BBC World Service. https://www.bbc.co.uk/news/magazine-36139908

Bruton, G. D., Zahra, S. A. and Cai, L. (2018). Examining Entrepreneurship through Indigenous Lenses. Entrepreneurship Theory and Practice, 42(3), 351-361.

Cahn, M. (2008). Indigenous entrepreneurship, culture and microenterprise in the Pacific Islands: case studies from Samoa, Entrepreneurship and Regional Development, Vol. 20, Issue 1, pp. 1-18,

Chrisman, J.J. and Patel, P. (2012). Variations in R\&D investment in family and non-family firms: behavioural agency and myopic loss aversion perspectives. Academy of Management Journal, 55(1), pp. 267-293.

Collins, L.A. \& Fakoussa, R. (2015). Ethnic minority entrepreneurship: an examination of Pakistani entrepreneurs in the UK. Journal of Innovation and Entrepreneurship, 4, 2 (2015) doi:10.1186/s13731-014-0013-1

Collins, J., Morrison, M., Basu, P. K. \& Krivokapic-Skoko, B. (2017). Indigenous culture and entrepreneurship in small businesses in Australia, Small Enterprise Research, Vol. 24, Issue 1, pp. 36-48

Collins, M. (2017) Supporting Irish traveller entrepreneurship, Small Enterprise Research, 24:1, 88-92, DOI: 10.1080/13215906.2017.1289857 
Chrisman, J. J., Chua, J. H. \& Litz, R. (2003). A unified systems perspective of family firm performance: An extension and integration. Journal of Business Venturing, 18, 467472.

CNN (2013). Nigeria's Igbo Jews: 'Lost tribe' of Israel? By Chika Oduah, for CNN. February 4, 2013. https://edition.cnn.com/2013/02/01/world/africa/nigeria-jewsigbo/index.html

Dana, L-P., Ratten, V. and Honyenuga, B. Q. (ed.) (2018). Introduction to African Entrepreneurship, Palgrave studies of entrepreneurship in Africa, Palgrave Macmillan, New York. USA.

Dana, L. P., \& Ratten, V. (2017). International entrepreneurship in resource-rich landlocked African countries. Journal of International Entrepreneurship, 15(4), 416-435.

Deakins, D., Ram, M. Smallbone, D. \& Fletcher, M. (2015). Ethnic Minority Entrepreneurs and the commercial banks in the UK. In Ethnic Entrepreneurship: Structure and Process. Online 293-313. http://dx.doi.org/10.1016/S1074-7877(03)04014-5

Drakopoulou, D. S., Anderson, A. \& Jack, S. (2004). Doing Entrepreneurship. The Impact of Environmental and Cognitive Factors upon Entrepreneurial Action. IATB Journal, Vol. 1(1), 1-22

Ferreira, J. J., Fayolle, A., Ratten, V. \& Raposo, M. (2018) (Eds.), Entrepreneurial universities: collaboration, education and policies. Cheltenham: Edward Elgar Publishing Ltd.

Gartner, W. B. (2007). Entrepreneurial narrative and a science of the imagination, Journal of Business Venturing, Vol. 22 No. 5, pp. 613-627.

George, G., Corbishley, C., Khayesi, J. N., Haas, M. R. and Tihanyi, L. (2016). Bringing Africa in: Promising directions for management research. Academy of Management Journal, 59(2), 373-399.

Greidanus, N. S. and Sharpe, J. (2017). Indigenous Entrepreneurship: International Ventures in an Intra-Country Context. Academy of Management Proceedings, Vol. 2017, No. 1, 1-19 https://doi.org/10.5465/AMBPP.2017.16291abstract

Greidanus, N. S., \& Sharpe, J. (2017). Indigenous Entrepreneurship: International Ventures in an Intra-Country Context. In Academy of Management Proceedings (Vol. 2017, No. 1, p. 16291). Briarcliff Manor, NY 10510: Academy of Management.

Guardian (2016). Nigeria army denies killing 150 at Biafra demonstrations. Jason Burke and agencies. Thu 24 Nov 201617.06 GMT.

https://www.theguardian.com/world/2016/nov/24/nigeria-army-denies-killing-150-atbiafra-demonstrations

Guardian (2019). The Influence of the 'Umu Ada' Sect in Igboland. By Franklin Ugobude 03 November 2019 https://guardian.ng/life/the-influence-of-the-umu-ada-sect-inigboland/

Guardian Newspaper (2019). We spoke English to set ourselves apart': how I rediscovered my mother tongue. By Adaobi Tricia Nwaubani. 14 March 2019.

https://www.theguardian.com/news/2019/mar/14/we-spoke-english-to-set-ourselvesapart-nigeria-childhood-igbo-language

Habbershon, T. G. and Williams, M. L. (1999). A Resource-Based Framework for Assessing the Strategic Advantages of Family Firms'. Family Business Review, Vol. 12, No. 1, pp. 1-21.

Habbershon, T. G., Nordqvist, M. and Zellweger, T. (2010). Transgenerational entrepreneurship. In M. Nordqvist \& T. Zellweger (Eds.), Transgenerational entrepreneurship: Exploring growth and performance in family firms across generations (pp. 1-38). Cheltenham, England: Edward Elgar. 
Habbershon, T. G., Williams, M. L. and MacMillan, I. C. (2003). A unified systems perspective of family firm performance. Journal of Business Venturing, 18, 451-465

Harms, R., Walsh, S. T. and Groen, A. J. (2012). The strategic entrepreneurship process new avenues for research. International Journal of Entrepreneurial Behaviour \& Research, Vol. 18 No. 2, pp. 132-136

Henry, E. (2017). The creative spirit: emancipatory Māori entrepreneurship in screen production in New Zealand. Small Enterprise Research, 24(1), 23-35.

Hill, J. and McGowan, P. (1999). Small business and enterprise development: questions about research methodology. International Journal of Entrepreneurial Behaviour \& Research, Vol. 5 No. 1, pp. 5-18

Hindle, K. (2005). Contrasting Indigenous entrepreneurship in Australia and Canada: How three applied research perspectives can improve policy and programs. Small Enterprise Research, 13(1), 92-106.

Hindle, K. and Lansdowne, M. (2005). Brave Spirits on New Paths: Toward a Globally Relevant Paradigm of Indigenous Entrepreneurship Research, Journal of Small Business \& Entrepreneurship, 18(2), pp.131-141, https://doi.org/10.1080/08276331.2005.10593335

Igwe, P. A., Hack-Polay, D., Mendy, J., Fuller, T. and Lock, D. (2019). Improving higher education standards through reengineering in West African universities - A case study of Nigeria. Studies in Higher Education, [Online First] https://doi.org/10.1080/03075079.2019.1698534

Igwe, P. A. and Icha-Ituma, A. (2020). A Review of Ten Years of African Entrepreneurship Research. In Book: Research Handbook on Entrepreneurship in Emerging Economies: A Contextualized Approach. (e.d), Akoorie, M. A. E, Gibb, J., Scott, J. M. and Sinha, P. (2020). Edward Elgar Publishers. Cheltenham, UK

Igwe, P. A., Newbery, R., Nihar, A., White, G. R. T. and Madichie, N. O. (2018). Keeping it in the family: exploring Igbo ethnic entrepreneurial behaviour in Nigeria. International Journal of Entrepreneurial Behavior \& Research, [Online First] https://doi.org/10.1108/IJEBR-12-2017-0492

Igwe, P.A., Onjewu, A.E. and Nwibo, S.U. (2018). Entrepreneurship and SMEs' productivity challenges in Sub-Saharan Africa. In Léo-Paul, D., Vanessa, R. and Honyenuga, B.Q. (Eds), African entrepreneurship: challenges and opportunities for doing business, Palgrave Macmillan, New York. USA

Iyer, G.R. (2004). Ethnic Business Families. In Ethnic Entrepreneurship: Structure and Process. International Research in the Business Disciplines, 4 (1), pp. 243-260.

Jaskiewicz, P., Combs, J. G. and Rau, S. B. (2015). Entrepreneurial legacy: Toward a theory of how some family firms nurture transgenerational entrepreneurship. Journal of Business Venturing, 30, 29-49.

Jones, J., and Smith, J. (2017). Ethnography: challenges and opportunities. Evidence-Based Nursing 20: 98-100.

Kammerlander, N., Dessì, C., Bird, M., Floris, M. and Murru, A. (2015). The impact of shared stories on family firm innovation: A multicase study. Family Business Review, $28,332-354$.

Kansikas, J., Laakkonen, A., Sarpo, V. and Kontinen, T. (2012). Familiness as a resource for strategic entrepreneurship. International Journal of Entrepreneurial Behaviour \& Research, Vol. 18 (2), 141-158

Kim, P. H. and Aldrich, H. E. (2005). Social Capital and Entrepreneurship. Boston: Now. In: Kwon, et al., (2013). Community Social Capital and Entrepreneurship. American Sociological Review, 78(6) 980-1008 
Kwon, S-W., Heflin, C. and Ruef, M. (2013). Community Social Capital and Entrepreneurship. American Sociological Review, 78(6) 980-1008

Le Breton-Miller, I., Miller, D. and Steir, L. (2004). Toward an integrative model of effective FOB succession. Entrepreneurship Theory and Practice, 28(1), pp. 305-328.

Leslie, M., Paradis, E., Gropper, M. A., et al. (2014). Applying ethnography to the study of context in healthcare quality and safety', BMJ Quality \& Safety, Vol. 23, pp. 99-105

Light, I. and Dana, L.-P. (2013). Boundaries of social capital in entrepreneurship. Entrepreneurship Theory and Practice, 37(3), 603-624.

Madichie, N. O., Gbadamosi, A., \& Nwankwo, S. (2018). Entrepreneurialism in a London university: a case illustration. In J. J. Ferreira, A. Fayolle, V. Ratten, \& M. Raposo (Eds.), Entrepreneurial universities: collaboration, education and policies (pp. 88104). Cheltenham: Edward Elgar Publishing Ltd. https://doi.org/10.4337/9781786432469.00009

Madichie, N. O. and Ayasi, K. (2018). Entrepreneurial Opportunities and Challenges for Retired Senior Military Officers in Nigeria. In: Dana, L-P., Ratten, V. and Honyenuga, B. Q. (ed.) (2018), Introduction to African Entrepreneurship, Palgrave studies of entrepreneurship in Africa, Palgrave Macmillan, New York. USA.

Madichie, N. O., \& Nkamnebe, A. D. (2010a). 51 Iweka Road (Onitsha, Nigeria): could this single African address redefine business cluster development? World Review of Entrepreneurship, Management and Sustainable Development, 6(3), 229-243.

Madichie, N. O., \& Nkamnebe, A. D. (2010b). Micro-credit for microenterprises? A study of women "petty" traders in Eastern Nigeria. Gender in Management: An International Journal, 25(4), 301-319.

Madichie, N. O., Nkamnebe, A. D., \& Idemobi, E. I. (2008). Cultural determinants of entrepreneurial emergence in a typical sub-Sahara African context. Journal of Enterprising Communities: People and Places in the Global Economy, 2(4), 285-299.

Mbeteh, A. \& Pellegrini, M. M. (2018). Entrepreneurship education in developing countries: A study of the key challenges in Sierra Leone. In: Dana, L-P., Ratten, V. and Honyenuga, B. Q. (ed.) (2018), Introduction to African entrepreneurship, Palgrave studies of entrepreneurship in Africa, Palgrave Macmillan, New York. USA.

Meagher, K. (2010). Identity Economics: Social Networks and the Informal Economy in Nigeria, Textbook Published by Boydell \& Brewer, Rochester, NY, available at: http://eprints.lse.ac.uk/id/eprint/27379 (accessed 10 April 2017)

Marquis, C., and Tilcsik, A. (2013). Imprinting: Toward a multilevel theory. Academy of Management Annals, 7, 195-245.

Monahan, T., \& Fisher, J. A. (2010). Benefits of 'observer effects': lessons from the field. Qualitative Research, 10(3), 357-376.

Moser, A. \& Korstjens, I. (2018), Series: Practical guidance to qualitative research. Part 3: Sampling, data collection and analysis. European Journal of General Practice, 24:1, 9-18 DOI: 10.1080/13814788.2017.1375091

Naudè, W. A. \& Havenga, J. J. D. (2005). An overview of African entrepreneurship and small business research', Journal of Small Business and Entrepreneurship, 18(1), 101-120.

Naude, W., Szirmai, A. \& Guedhuys, M. (2011). Innovation and entrepreneurship in developing countries, Policy Brief No. 1, United Nation's University, Helsinki, Finland.

Nwankwo, S., Madichie, N., \& Ekwulugo, F. (2011). Researching African entrepreneurship in the UK. African entrepreneurship in global contexts: enterprise solution to sustainable development. WASD, London, 61-74. 
Nordqvist, M., Wennberg, K.J., Bau, M. \& Hellerstedt, K. (2013). An entrepreneurial process perspective on succession in family firms. Small Business Economics. 40(1), 10871122.

Oyelaran-Oyeyinka, B. (2004).Networking technical change and industrialization. The Case of Small and Medium Firms in Nigeria, ATPS Special Paper Series No. 20, African Technology Policy Studies Network, African Technology Policy Studies Network, Nairobi.

Palinkas, L. A., Horwitz, S. M., Green, C.A., Wisdom, J. P., Duan, N. \& Hoagwood, K. (2015). Purposeful sampling for qualitative data collection and analysis in mixed method implementation research. Administration and Policy in Mental Health, 42(5), 533-544.

Powell, G. N. \& Eddleston, K.A. (2016). Family involvement in the firm, family-to-business support, and entrepreneurial outcomes: an exploration. Journal of Small Business Management, 55(4), 614-631

Ram, M. \& Holliday, R. (1993). Relative merits: family culture and kinship in small firms', Sociology, 27(4), 630-648.

Rath, J. (2000). Introduction: Immigrant businesses and their economic, politico-institutional and social environment'. In Rath, J. (Ed.) Immigrant Businesses. The Economic, Politico-institutional and Social Environment. Basingstoke, Macmillan, pp. 1-19.

Ratten, V. (2014). Encouraging collaborative entrepreneurship in developing countries: the current challenges and a research agenda. Journal of Entrepreneurship in Emerging Economies, 6(3), 298-308.

Ratten, V. \& Jones, P. (2018). Bringing Africa into entrepreneurship research, In Dana, L.P., Honyenuga, B.Q. and Ratten, V. (ed.), (2018), Challenges and opportunities for doing business, Palgrave studies of entrepreneurship in Africa, Cheltenham: Palgrave Macmillan. New York. USA.

Ritchie, J. \& Lewis J. (2013). Qualitative research practice: a guide for social science students and researchers. 2nd ed. London: Sage Publications

Rolfe, G. (2006). Validity, trustworthiness and rigour: quality and the idea of qualitative research", Journal of Advanced Nursing, 53(3), 304-310.

Sharafizad, J. \& Coetzer, A. (2016). The networking interactions of Australian women small business owners. Small Enterprise Research, 23(2), 135-150, DOI: 10.1080/13215906.2016.1221362

Sundaramurthy, C. (2008). Sustaining trust within family businesses, Family Business Review, 21(1), 89-102.

Seaman, C. (2015). Creating space for the business family: Networks, social capital \& family businesses in rural development. Journal of Family Business Management, 5(2), 182191.

Selling, N. \& Svallfors, S. (2019). The Lure of Power: Career Paths and Considerations among Policy Professionals in Sweden. Politics \& Policy, 47(5), 984-1012. 10.1111/polp.12325

Tata, J. \& Prasad, S. (2015). Immigrant family businesses: social capital, network benefits and business performance. International Journal of Entrepreneurial Behaviour and Research, 21(6), 842-866.

The Editors of Encyclopaedia (n.d.). Igbo People, Britannica https://www.britannica.com/topic/Igbo

Wikipedia (2019). Igbo Culture. 2 November 2019 https://en.wikipedia.org/wiki/Igbo_culture Yuan, W. \& Wu, Z. (2017). A Value Perspective of Family Firms. Entrepreneurship Theory and Practice, 42(2), 283-289. 
Yu, A., Lumpkin, G. T., Sorenson, R. L. \& Brigham, K. H. (2012). The landscape of family business outcomes: A summary and numerical taxonomy of dependent variables. Family Business Review, 25, 33-57.

Zellweger, T. M., Chrisman, J. J., Chua, J. H. \& Steier, L. P. (2019). Social Structures, Social Relationships, and Family Firms. Entrepreneurship Theory and Practice, 43(2), 207223. https://doi.org/10.1177/1042258718792290

Zhu, F., Burmeister-Lamp, K. \& Hsu, D.K. (2017). To leave or not? The impact of family support and cognitive appraisals on venture exit intention", International Journal of Entrepreneurial Behaviour \& Research, 23(3), 566-590.

Zhou, M. (2004). Revisiting ethnic entrepreneurship: Convergencies, controversies, and conceptual Advancements. International Migration Review, 38(3), 1040-1074. doi: $10.1111 / \mathrm{j} .1747$ 